\title{
Germination requirements of flameleaf sumac
}

\section{G. ALLEN RASMUSSEN AND HENRY A WRIGHT}

\begin{abstract}
Germination characteristics of flameleaf sumac (Rhus lanceolata) seeds were determined in a controlled environmental growth chamber using a short-day cycle ( $8 \mathrm{hr}$ light/16 dark). Seeds must be scarified before germination can occur. Heat treatments can scarify nameleaf sumac seeds if temperatures reach $76^{\circ} \mathrm{C}$ in wet environments or $82^{\circ} \mathrm{C}$ in dry environments. Once searified, germination of seeds occurred under a wide range of temperatures $\left(10-25^{\circ} \mathrm{C}\right)$ and $\mathrm{pH}(4-10)$. However, maximum germination of flameleaf sumac occurred when seeds were subjected to alternating temperatures of $10 / 20^{\circ} \mathrm{C}$ with a short-day light cycle. Surrounding medium must have a high osmotic potential ( -0.1 megapascal) and a pH of 10 for maximum germination. Fire enhances these conditions thus aiding the establishment of flameleaf sumac following burning. No differences in emergence occurred when seeds were placed 0 to $6 \mathrm{~cm}$ in the soil profile.
\end{abstract}

Key Words: prescribed burning, scarification, optimum temperature, soil pH, pretreatments

Flameleaf sumac (Rhus lanceolata) is a large deciduous shrub (usually 2 to $4 \mathrm{~m}$ tall) which occurs on limestone and calcareous soils from central Texas, north to Oklahoma, and west into New Mexico. Flameleaf sumac has small, whitish flowers on a terminal thyrse, which can be as large as 10 by $7 \mathrm{~cm}$. Fruits are red somewhat flattened drupes $4 \mathrm{~mm}$ long. Leaves are compound with 13 to 19 sessil, linear lanceolate leaflets $55 \mathrm{~mm}$ long and $12 \mathrm{~mm}$ wide

Authors are research assistant and Horn professor, Department of Range and Wildlife Management, Texas Tech University, Lubbock 79409. This is Texas Tech University College of Agriculture Sciences Publication No. T-9-467.

Manuscript accepted 22 September 1987.
(Correll and Johnston 1979).

Flameleaf sumac is a minor component of climax woody vegeta. tion in the Edwards Plateau resource region of Texas and is an early succession species following wildfires (Huss 1954). Current interest in using prescribed fire on areas where flameleaf sumac occurs may cause flameleaf sumac to increase its dominance, to a point where it is beginning to be a serious brush problem for some land managers. Flameleaf sumac is considered a valuable wildlife plant for browse and mast production, with its seeds spread primarily by birds and small mammals (Brinkman 1974).

Dormancy of $R$ hus sp. seeds is generally caused by a hard seed coat which restricts imbibition. To release this dormancy $R$ hus sp. seeds must be scarified. Scarification is a process which makes the seed coat permeable to water and/or gases. Rhus trilobata and Rhus aromatica, also require a cold stratification in addition to scarification before germination will occur (Boyd 1943, Heit 1967). Neither Boyd (1943) or Heit (1967) found a stratification requirement for flameleaf sumac.

Huss (1954) noted that germination of flameleaf sumac increased after fire passed over the seeds. Similarly, other researchers have found that heat from fire enhances germination of redstem ceanothus (Ceanothus sanginuneus) (Orme and Leege 1976) and many legumes (Martin and Cushwa 1966). Heat caused the waxy plug in hilar fissure to open, allowing moisture to enter the seed (Orme and Leege 1976). Cushwa et al. (1968) found that thermal conductivity of the medium surrounding the seeds affected legume seed germination. When the environment was moist, heat was more effective in scarifying the seeds; germination variability decreased; and percent germination increased. 
Information is limited on basic germination requirements of flameleaf sumac, and this study was initiated to gain information on seedbed characteristics required by flameleaf sumac and determine if fire has a role in its establishment.

\section{Materials and Methods}

Seeds of flameleaf sumac were collected from at least 25 plants in February 1984 and March 1986 on Spring Mesa in Callahan County, $24 \mathrm{~km}$ southeast of Baird, Texas. Once collected, seeds were removed from their fruits as suggested by Brinkman (1974). Only fully developed seeds obtained by hand separation were used for germination experiments; irregular shaped seeds were excluded. Seeds were stored in the laboratory at room temperature. Experiments were conducted in small, environmental growth chambers with automatic temperature and light controls. Unless stated, all experiments were conducted at $20^{\circ} \mathrm{C}$ using a short-day cycle ( 8 hours light / 16 hours dark). White fluorescent light with an average photosynthetic photon flux density of $20 \mathrm{~mol} \mathrm{~m}^{-2} \mathrm{~s}^{-1}$. An open 4-liter pan of water was kept in the environmental chamber to maintain a high relative humidity.

All experiments were arranged in a completely random design with 4 or 5 replications per treatment. A seed was considered germinated if its radical was $\mathbf{2} \mathbf{~ m m}$ long. Percent germination data were transformed using the square root of the arcsin before analysis and mean separation tests were performed (Steel and Torrie 1980). Student-Newman-Keul's range test $(P \leq 0.05)$ was used to seperate means. Values were converted back to actual means for presentation. An experimental unit consisted of 30 seeds placed on 2 pieces of filter paper in a 9-cm petri dish with $8 \mathrm{ml}$ of distilled water or the appropriate treatment solution. Each experiment was run for 15 days and repeated twice unless stated otherwise. In all cases no significant difference occurred $(P \leq 0.05)$ between experiments so data were pooled to facilitate analysis.

\section{Temperature and Light}

Constant temperature ranging from 5 to $35^{\circ} \mathrm{C}$ at 5 -degree increments were used to determine the constant temperature where maximum germination of flameleaf sumac occurred. This temperature is referred to as the optimum constant temperature in this study. Rhus sp. germinate in the spring and have a higher percent germination in presence of light compared to total darkness (Heit 1967). Using this information, we compared seeds germinated in a short-day light cycle ( 8 hour light/ 16 hour dark) to those germinated in total darkness. Light was excluded from seeds by wrapping petri dishes in aluminum foil. Brinkman (1974) suggested germination of Rhus sp. would be enhanced if seeds were scarified so half the seeds were soaked in concentrated sulfuric acid $\left(\mathrm{H}_{2} \mathrm{SO}_{4}\right)$ (18M) for 30 minutes, then rinsed with 5 liters of distilled water, immediately before initiation of the experiment. Each treatment was replicated 5 times and analyzed as a factorial with light, scarification, and temperature as independent factors (Steel and Torrie 1980). Seeds used were collected in 1984.

Using conditions which resulted in maximum germination of flameleaf sumac seeds ( $20^{\circ} \mathrm{C}$ and the short-day light cycle), we conducted a separate experiment using 2 alternating temperatures of $10 / 20$ and $20 / 30^{\circ} \mathrm{C}$ and the constant temperature of $20^{\circ} \mathrm{C}$. During alternating temperature treatments the 8-hour light period was timed to coincide with the high temperature. This study was arranged in a completely random design and analyzed using oneway analysis of variance. Seeds used were collected in 1984.

\section{Scarification}

Methods of scarification included dry and wet heat, concentrated $\mathrm{H}_{2} \mathrm{SO}_{4}$, alternately freezing and thawing, and mechanically scratching the surface. For dry heat treatments, seeds in waterproof plastic bags were placed in a water bath at $50,70,73,76,79$, $82,85,88,91,94$, and $97^{\circ} \mathrm{C}$. Wet heat treatments were accomplished by placing a $1-\mathrm{cm}$ piece of foam rubber saturated with distilled water in the plastic bag and allowing it to equilibrate with the temperature of the water bath before seeds were added to the bag. The same temperatures were used for wet and dry heat treatments. Seeds were left in the water bath for 3 minutes. Concentrated $\mathrm{H}_{2} \mathrm{SO}_{4}$ treatments involved soaking the seeds for $0,15,30$, 45 , and 60 minutes. Immediately following the acid treatment, seeds were rinsed with 5 liters of distilled water in a Buchner funnel to remove any $\mathrm{H}_{2} \mathrm{SO}_{4}$ left on seeds. Seeds were alternately frozen $\left(-4^{\circ} \mathrm{C}\right)$ for $12 \mathrm{hr}$ and thawed for $2 \mathrm{hr}\left(24^{\circ} \mathrm{C}\right) 4$ times. Mechanically scratching the surface of the seed with a file was the final scarification treatment. Seeds used in this experiment were collected in 1984. Each treatment was replicated 4 times and analyzed using a one-way analysis of variance.

Average imbibition weight of flameleaf sumac seeds were determined by placing seeds scarified for 1 hour with $\mathrm{H}_{2} \mathrm{SO}_{4}$ and unscarified seeds in a petri desk with $10 \mathrm{ml}$ of distilled water. Seeds were weighed prior to being placed in the petri dish then at $1,2,4,8,16$, $24,48,72,96$, and 120 hours after being placed in the environmental growth at $20^{\circ} \mathrm{C}$ with a short-day light cycle. Only the terminal 120-hour time period is presented. The scarified seed treatment was terminated when germination occurred. Unscarified seeds were kept in the germinator and weighed for $\mathbf{3 0}$ days. An experimental unit consisted of 100 seeds. Three replications per treatment were used and the experiment was conducted twice. The 2 experiments were pooled and a $t$-test $(P \leq 0.05)$ was used to compare the unscarified and scarified seeds.

\section{Osmotic Potential}

Moisture stress effects on germination of the seeds were simulated using an aqueous solution of polyethylene glycol (PEG) molecular weight 6,000 daltons mixed to exert osmotic potentials of $0,-0.1,-0.3,-1.0$, and -1.5 megapacals (MPa) (Michel and Kaufmann 1973). Experiments were conducted in July 1986 with seeds collected in March 1986. To reduce evaporation, petri dishes were sealed with plastic. Each petri dish received $10 \mathrm{~m}$ of the appropriate PEG solution. Each treatment was replicated 5 times.

\section{Hydrogen Ion Concentration}

The effect of hydrogen ion concentration (pH) on flameleaf sumac was determined by adjusting the $\mathrm{pH}$ of distilled water with hydrochloric acid to lower the $\mathrm{pH}$ or potassium hydroxide to raise the pH (Mayeux and Scifres 1978). The $\mathrm{pH}$ levels used were 4, 6, 8, 10, and 12. Each treatment was replicated 5 times with seeds collected in March 1986.

\section{Depth of Seed Pincement}

Effect of depth of seed placement was determined using soil cups $9 \mathrm{~cm}$ in diameter and $10 \mathrm{~cm}$ deep. A clay loam soil was dried then ground to pass through a 25- $\mathrm{mm}^{2}$ screen. Each cup was filled with $285 \mathrm{~g}$ of soil. Seeds which had been scarified by soaking in concentrated $\mathrm{H}_{2} \mathrm{SO}_{4}$ for $1 \mathrm{hr}$ were placed in groups of 50 at $0,0.5,1.0,1.5$, 3.0 , or $6.0 \mathrm{~cm}$ beneath the surface. Each depth was replicated 3 times using a total of 150 seeds collected in March 1986. Final emergence was reported after 45 days.

\section{Results and Discussion}

\section{Temperature}

Unscarified seed did not germinate regardless of temperature or light. Therefore, only scarified seeds in the temperature and light treatment were analyzed. There was a significant interaction $(P \leq 0.05)$ between the temperature and light treatments (Table 1). When the seeds were subjected to total darkness, percent germination was reduced in most cases. However, the $15^{\circ} \mathrm{C}$ treatment in darkness did not reduce germination. Temperature treatments of 15 and $20^{\circ} \mathrm{C}$ had the highest percent germination in total darkness. However, when seeds were exposed to 8 hours light / 16 hours dark, maximum germination occurred at $20^{\circ} \mathrm{C}$ (Table 1 ).

Percent germination of seeds between the 2 alternating temperatures $\left(10 / 20\right.$ and $20 / 30^{\circ} \mathrm{C}$ ) and the constant temperature of $20^{\circ} \mathrm{C}$ was different $(P \leq 0.05)$. Germination was 30,20 , and $14 \%$ for the 
Table. 1. Percent germination of $\mathrm{H}_{2} \mathrm{SO}_{4}$ scarified flameleaf sumac seeds collected in February 1984, at contant temperatures under a short-day light cycle (SDC) (8 hours light/ 16 hours dark) or total darimess after 15 days in the environmental chamber.1

\begin{tabular}{lcc}
\hline \hline Temperature & \multicolumn{2}{c}{ Light } \\
\cline { 2 - 3 }$\left({ }^{\circ} \mathrm{C}\right)$ & SDC & Dark \\
\hline 5 & $0 \mathrm{~A} \mathrm{c}$ & $0 \mathrm{~A} \mathrm{~b}$ \\
10 & $0 \mathrm{~A} \mathrm{c}$ & $0 \mathrm{~A} \mathrm{~b}$ \\
15 & $4 \mathrm{~A} \mathrm{bc}$ & $7 \mathrm{~A} \mathrm{a}$ \\
20 & $20 \mathrm{~A} \mathrm{a}$ & $11 \mathrm{~B} \mathrm{a}$ \\
25 & $8 \mathrm{~A} \mathrm{~b}$ & $3 \mathrm{~B} \mathrm{~b}$ \\
30 & $1 \mathrm{~A} \mathrm{c}$ & $1 \mathrm{~A} \mathrm{~b}$ \\
35 & $0 \mathrm{~A} \mathrm{c}$ & $0 \mathrm{~A} \mathrm{~b}$ \\
\hline
\end{tabular}

'Means followed by the same capital letter within a row or the same small letter in a column are not significantly different according to Student-Newman-Kuel's mean separation test $(P \leq 0.05)$.

$10 / 20$, and $20 / 30^{\circ} \mathrm{C}$ treatments, respectively. Alternating temperatures at $10 / 20^{\circ} \mathrm{C}$ increased germination $50 \%$ over the constant $20^{\circ} \mathrm{C}$ treatment. In contrast, when the $20^{\circ} \mathrm{C}$ temperature was used as the minimum and $30^{\circ} \mathrm{C}$ was used as the maximum, germination declined $30 \%$.

\section{Scarification}

The best scarification treatments were mechanically scratching the surface or wet heat at 94 or $97^{\circ} \mathrm{C}$ (Table 2). Seeds which were

Table 2. Percent germination of nameleaf sumac after 15 days in an environmental chamber at $20^{\circ} \mathrm{C}$ with a short-day light cycle (8 hours bight/16 hours dark) following various scarification techniquesi.

\begin{tabular}{|c|c|c|}
\hline \multicolumn{2}{|l|}{ Treatment } & \multirow{2}{*}{$\frac{\text { Germination (\%) }}{43 \mathrm{a}}$} \\
\hline Mechanical & & \\
\hline Freeze + thaw & $\left(-4+20^{\circ} \mathrm{C}\right)$ & $0 \mathrm{i}$ \\
\hline Dry Heat $\left({ }^{\circ} \mathrm{C}\right)$ & 50 & $0 \mathrm{i}$ \\
\hline & 70 & $0 \mathrm{i}$ \\
\hline & 73 & $0 \mathrm{i}$ \\
\hline & 76 & $0 \mathrm{i}$ \\
\hline & 79 & $1 \mathrm{i}$ \\
\hline & 82 & $4 \mathrm{gh}$ \\
\hline & 85 & $5 \mathrm{gh}$ \\
\hline & 88 & $15 \mathrm{de}$ \\
\hline & 91 & $5 \mathrm{fg}$ \\
\hline & 94 & $7 \mathrm{fg}$ \\
\hline & 97 & $15 \mathrm{de}$ \\
\hline \multirow[t]{11}{*}{ Wet Heat } & 50 & $0 \mathrm{i}$ \\
\hline & 70 & $0 \mathrm{i}$ \\
\hline & 73 & $3 \mathbf{h i}$ \\
\hline & 76 & $11 \mathrm{ef}$ \\
\hline & 79 & 17 de \\
\hline & 82 & $7 \mathrm{df}$ \\
\hline & 85 & $20 \mathrm{de}$ \\
\hline & 88 & 20 de \\
\hline & 91 & $26 \mathrm{bc}$ \\
\hline & 94 & $37 \mathbf{a}$ \\
\hline & 97 & $33 \mathrm{ab}$ \\
\hline $\mathrm{H}_{2} \mathrm{SO}_{4}(\mathrm{~min})$ & 15 & $6 \mathrm{fg}$ \\
\hline & 30 & $11 \mathrm{ef}$ \\
\hline & 45 & $15 \mathrm{de}$ \\
\hline & 60 & $22 \mathrm{~cd}$ \\
\hline \multicolumn{2}{|l|}{ Untreated } & $0 \mathrm{i}$ \\
\hline
\end{tabular}

'Means followed by the same letter are not significantly different according to Student-Newman-Kuel's mean separation test $(P \leq 0.05)$.

not scarified did not germinate. Freezing and thawing and heat treatments of less than $73^{\circ} \mathrm{C}$ did not increase germination above the untreated seeds (Table 2). Dry heat did not increase germination until temperatures reached $82^{\circ} \mathrm{C}$. Wet heat increased germination at a lower temperature $\left(76^{\circ} \mathrm{C}\right)$ compared to the dry heat treatments. The lower temperature of $76^{\circ} \mathrm{C}$ required for heat scarification of flameleaf sumac seeds in a moist environment is attributed to the increased thermal conductivity properties of water. Heat has also been shown to break the seed coat of Rhus ovata and allow imbibition of the seed (Stone and Juhren 1951).

Heat ruptured flameleaf sumac seed coats as well as broke the waxy cutical (Fig. 1). The major openings on the heated seeds were at the hilar pore and hilar fissure region with other cracks radiating away from these regions. Orme and Leege (1976) found that the waxy plug in the hilar fissure is removed in restem ceanothus while these data suggest that the flameleaf sumac's seed coat is damaged directly. The widening of the cracks appears to be the major avenue for moisture absorption. Cracks found on untreated seeds were 6 , which apparently was not sufficient to allow moisture absorption. Seed cutical was also disrupted by heating, which may enhance further water penetration into the seed (Fig. 1). These results suggest prescribed fire on rangelands can effectively break down the seed coat sufficiently to allow imbibition of the seed, provided the seeds are close enough to the surface to be heated above $82^{\circ} \mathrm{C}$. In very intense fires, seeds on or close to the surface may be destroyed.

Prescribed fires in Ashe juniper (Juniperus ashei) communities are often conducted with high soil moisture. This may enhance establishment of the flameleaf sumac since temperatures of $76^{\circ} \mathrm{C}$ are readily achieved within $2 \mathrm{~cm}$ of the soil surface (Rasmussen et al. 1986). Where brush has been piled, these temperatures are capable of penetrating even deeper into the soil profile (Wright and Bailey 1982). Under dry soil conditions thermal conductivity properties are reduced, allowing less heat to diffuse deeper into soil. However, seeds on or close to the surface can be scarified because of increased temperatures at the surface. Increasing dry heat temperatures did not consistently increase germination (Table 2). This variability was also noted in legume seeds which were scarified with dry heat (Cushwa et al. 1968). The reduced germination variability of wet heat treatments was attributed to thermal conductivity properties of water.

Germination of seeds scarified with $\mathrm{H}_{2} \mathrm{SO}_{4}$ was greatest when they were soaked for 60 minutes but was below that of wet heat treatments of 94 and $97^{\circ} \mathrm{C}$, and of mechanically scratching the surface. As time in $\mathrm{H}_{2} \mathrm{SO}_{4}$ increased, percent germination increased (Table 2). Tischler and Young (1983) found $\mathrm{H}_{2} \mathrm{SO}_{4}$ treatments broke seed dormancy by removing chemical germination inhibitors. While this study did not specifically test for chemical germination inhibitors, effectiveness of mechanical scarification suggests chemical inhibitors are not present. Freezing and thawing flameleaf sumac seed did not allow germination; however, freeze and thaw treatments used may not have been long enough to break down the seed coat.

Seed coat prevented germination by restricting water absorption. Scarified seeds absorbed an average of $0.4431( \pm 0.0170) \mathrm{mg}$ of water in the 5 days before radical emergence occurred, which was significantly greater $(P \leq 0.05)$ than that absorbed by unscarified seeds, namely, $0.0077( \pm 0.0063) \mathrm{mg}$ in the same time period. Unscarified seeds gained only $0.0110 \mathrm{mg}$ after 30 days in the petri dish. Weight gain of unscarified seeds may have been moisture adhering to the outside of seeds since they were only blotted dry. The same amount of moisture could have been absorbed by scarified seeds, though it was only $2 \%$ of the total water absorbed. This evidence and the results of other scarification treatments (mechanical, heat, and acid) indicate flameleaf sumac domancy is related to restriction of water absorption by seed coat.

\section{Osmotic Potential}

Germination was reduced when flameleaf sumac seeds were subjected to low osmotic potentials (Table 3). Germination remained high at an osmotic potential of $-0.1 \mathrm{MPa}$ but was reduced $83 \%$ when osmotic potential was lowered to $-0.3 \mathrm{MPa}$. Seedling fresh weights for the -0.1 and $-0.3 \mathrm{MPa}$ stress levels were reduced by 92 and $94 \%$, respectively, compared to those in distilled water (Table 3). This suggests that seeds which germinate under these conditions may have a limited ability to survive because of 


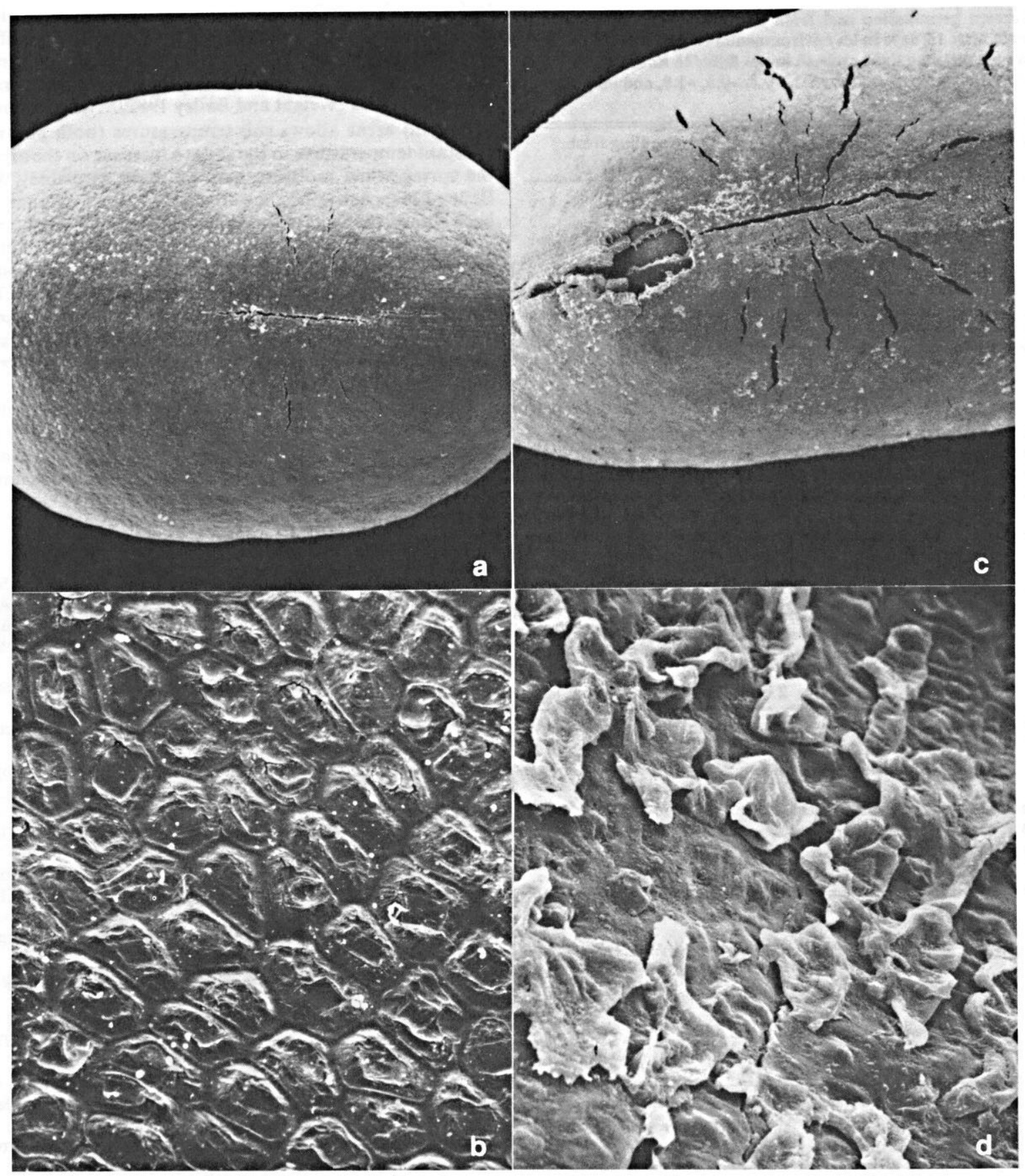

Fig. 1. Appearance of untreated $(a \times 45$ and $b \times 1000)$ and heat treated $\left(97^{\circ} C\right.$ for 3 min. $c \times 45$ and $\left.d \times 1000\right)$ flameleaf sumac seeds. Scanning electron micrographs using a Toshiba 10 scanning electron microscope.

reduced size. While this study did not look at effect of soil matrix potential on flameleaf sumac seed germination, these data suggest a high soil water content will be needed.

\section{Hydrogen Ion Concentration}

Flameleaf sumac seeds are capable of germinating under a wide range of soil pH (Table 4). Highest germination occurred in a solution with a pH of 10 . Germination rate remained high at $\mathrm{pH} 4$, 6 , and 8 . The only hydrogen concentration used in this experiment which dramatically reduced germination, seedling fresh weights, and length of radical was a pH of 12 (Table 4). Soils where seeds were collected on Spring Mesa had relatively high $\mathrm{pH}$ levels (7.4-8.4), although they did not approach the germination optimum of 10 . Soil $\mathrm{pH}$ increases following burning, though it is generally for a short period of time. This increase in $\mathrm{pH}$ can be as high as $2 \mathrm{pH}$ levels (Stewart and Flinn 1985, Wright and Bailey 1982). They attributed the increased $\mathrm{pH}$ to ash deposition on burned areas.

\section{Depth of Seed Placement}

Depth that seeds were placed in the soil $(0$ to $6 \mathrm{~cm})$ did not affect percent emergence (Table 5), although emergence tended to decrease as depth of seed placement increased (Table 5). Sufficiently scarified seeds at the deeper depths could have improved chances of survival because once the soil profile is wetted to a depth of $6 \mathrm{~cm}$ at field capacity, it would not dry as quickly as the surface.

These studies suggest flameleaf sumac can germinate, once scarified, in a wide range of environments if moisture was available. 
Table 3. Porcent germination and freah seeding weithts of nameleaf sumac seeds after 15 days in an environmental chamber maintained at $20^{\circ} \mathrm{C}$ and a short-day lipht cycle (8 hour light/16 hours dark) when subjected to molsture atreas at $0,-0.1,-0.3,-0.5,-1.0$, and $-1.5 \mathrm{MPa1}$.

\begin{tabular}{ccc}
\hline \hline $\begin{array}{c}\text { Moisture stress } \\
(\mathrm{MPa})\end{array}$ & $\begin{array}{c}\text { Germination } \\
(\%)\end{array}$ & $\begin{array}{c}\text { Seedling fresh } \\
\text { weight (mg) }\end{array}$ \\
\hline 0 & $71 \mathrm{a}$ & $25 \mathrm{a}$ \\
-0.1 & $57 \mathrm{~b}$ & $2 \mathrm{~b}$ \\
-0.3 & $12 \mathrm{c}$ & $1 \mathrm{~b}$ \\
-0.5 & $\mathrm{~T} \mathrm{~d}$ & $\mathrm{~T} \mathrm{c}$ \\
-1.0 & $0 \mathrm{~d}$ & $0 \mathrm{c}$ \\
-1.5 & $0 \mathrm{~d}$ & $0 \mathrm{c}$ \\
\hline
\end{tabular}

'Means followed by the same letter are not significantly different according to Student-Newman-Kuel's mean separation test $(P \leq 0.05)$.

Table 4. Percent germination, seedling weight and radical len the of flameleaf aumac seed collected in March 1985 when subjected to pH levels of 4, $6,8,10$, and 12 after 15 days in an environmental chamber maintained at $20^{\circ} \mathrm{C}$ and a short-day light cyclet (8 hours lifht/16 hours dark).

\begin{tabular}{cccc}
\hline \hline pH & $\begin{array}{c}\text { Germination } \\
(\%)\end{array}$ & $\begin{array}{c}\text { Seedling fresh } \\
\text { weight }(\mathbf{m g})\end{array}$ & $\begin{array}{c}\text { Radical length } \\
(\mathbf{m m})\end{array}$ \\
\hline 4 & $48 \mathrm{~b}$ & $25 \mathrm{a}$ & $13 \mathrm{a}$ \\
6 & $50 \mathrm{~b}$ & $26 \mathrm{a}$ & $11 \mathrm{a}$ \\
8 & $51 \mathrm{~b}$ & $26 \mathrm{a}$ & $11 \mathrm{a}$ \\
10 & $70 \mathrm{a}$ & $24 \mathrm{a}$ & $13 \mathrm{a}$ \\
12 & $6 \mathrm{c}$ & $2 \mathrm{~b}$ & $3 \mathrm{~b}$ \\
\hline
\end{tabular}

IMeans followed by the same letter within a column are not significantly different according to Student-Newman-Keul's mean separation test ( $P \leq 0.05$ ).

Table 5. Percent emerzence of flameleaf aumac planted at depths of 00.5 , $1.0,1.5,3.0,6.0 \mathrm{~cm}$ while in a growth chamber maintulned at $20^{\circ} \mathrm{C}$ and a short-day light cycle' (8 hours light/16 hours dark).

\begin{tabular}{cl}
\hline \hline $\begin{array}{c}\text { Depth } \\
(\mathrm{cm})\end{array}$ & Emergence \\
$(\%)$ \\
\hline 0 & $32 \mathrm{a}$ \\
0.5 & $25 \mathrm{a}$ \\
1.0 & $20 \mathrm{a}$ \\
1.5 & $19 \mathrm{a}$ \\
3.0 & $18 \mathrm{a}$ \\
6.0 & $15 \mathrm{a}$ \\
\hline
\end{tabular}

IMeans followed by the same letter are not significantly different according to Student-Newman-Kuel's mean separation test $(P \leq 0.05)$.

With the high moisture requirements needed for germination, this would be a severe limiting factor in a natural environment. However, with seeds able to emerge from as deep as $6 \mathrm{~cm}$, they could escape many of the wet-dry cycles which would occur close to the surface.

\section{Conclusions}

Flameleaf sumac becomes a dominant or subdominat brush species on prescribed burned areas in the Edwards Plateau resource area in Texas (Rasmussen 1986). This increase in flameleaf sumac can in part be explained by the impact of prescribed burning directly on the seed and indirectly on the seed bed. The most important impact prescribed burning would have on a flame- leaf sumac is scarification of the seed coat, allowing imbibition. Heat generated on or near the soil surface by fire is sufficient $\left(82^{\circ}\right.$ C) to scarify seeds (Rasmussen et al. 1986, Wink and Wright 1973). In areas where brush piles occur, temperatures can penetrate several centimeters (Wright and Bailey 1982). The blackened surface of burned areas allows soil temperatures (both alternating and constant temperatures in the soil) to increase on the area earlier in the spring when moisture may be more available (Wright and Bailey 1982). Ash left on the area after a fire is alkaline, which has been shown to increase the soil pH (Steward and Flynn 1985).

These alterations of an environment by fire can account for high germination of flameleaf sumac seen on burned areas, especially on areas which were previously covered with brush piles. These piles not only offer roosting sites and cover for birds and small mammals which are a primary distribution mechanism for sumac seed (Brinkman 1974) but also alter seed bed characteristics following fire.

Fire would remove competition on these hot spots, which would improve moisture conditions and push other conditions (e.g., scarification, temperature, and $\mathrm{pH}$ ) closer to the optimum for germination. These factors increase the chances of flameleaf sumac germination and establishment on burns.

\section{Literature Cited}

Brinkman, K.A. 1974. Rhus. L. Sumac. P. $715-719$ In: C.S. Schopmeyer (ed.) Seeds of woody plants in the United States. U.S. Dep. Agr. Handb. No. 450, USDA. U.S. Government Printing Office, Washington, D.C.

Boyd, I.L. 1943. Germination tests on 4 species of sumac. Trans. Kansas Acad. Sci., (Baldwin City) 46:85-86.

Correll, D.S., and M.C. Johnston. 1979. Manual of the vascular plants of Texas. Univ. Texas at Dallas. Richardson, Texas.

Cushwa, C.T., R.E. Martin, and R.L. Miller. 1968. The effects of fire on seed germination. J. Range Manage. 21:250-254.

Heit, C.H. 1967. Propagation from seed-Part 7. Successful propagation of 6 hard seeded group species. Amer. Nurseryman. 125:37-41.

Huss, D.L. 1954. Factors influencing plant succession following fire in Ashe juniper woodland types in Real County, Texas. M.S. Thesis. Texas A\&M Univ.

Martin, R.E., and C.T. Cuahwa. 1966. Effects of heat and moisture on leguminous seed. Proc. Tall Timbers Fire Ecol. Conf., Tallahassee, Florida. 5:159-175.

Mayeux, Jr., H.S., and C.J. Scifres. 1978. Germination of goldenweed seed. J. Range Manage. 31:371-374.

Michel, B.E., and M.R. Kaufmann. 1973. The osmotic potential of polyethylene glycol 6000. Plant Physiol. 51:914-916.

Orme, M.L., and T.A. Leege. 1976. Emergence and survival of redstem (Ceanothus sanguineus) following prescribed burning. Proc. Tall Timbers Fire Ecol. Conf., Missoula, Mont. 14:391-420.

Rasmussen, P.E., R.W. Rickman, and C.L. Douglas, Jr. 1986. Air and soil temperatures during spring burning of standing wheat stubble. Agron. J. 78:261-263.

Rasmusen, G.A. 1986. Long-term effects of prescribed fire on Ashe juniper communities. Diss. Texas Tech Univ., Lubbock.

Steel, R.G.D., and J.H. Torrie. 1980. Principles and procedures of statistics. 2nd Ed. McGraw-Hill Book Co., Inc., N.Y.

Stewart, H.T.L., and D.W. Flinn. 1985. Nutrient losses from broadcast burning of Eucaluptus debris in North-east Victoria. Aust. Forest Res. 15:321-332.

Stone, E.C., and G. Juhren. 1951. The effect of fire on germination of the seed of Rhus ovata Wats. Amer. J. Bot. 38:368-372.

Tiachler, C.R., and B.A. Young. 1983. Effects of chemical and physical treatments on germination of freshly-harvested kleingrass seed. Crop Sci. 23:389-792.

Wink, R.L., and H.A. Wright. 1973. Effects of fire on an Ashe juniper community. J. Range Manage. 26:326-329.

Wright, H.A., and A.W. Bailey. 1982. Fire ecology: United States and Southern Canada. John Wiley and Sons, Inc., N.Y. 